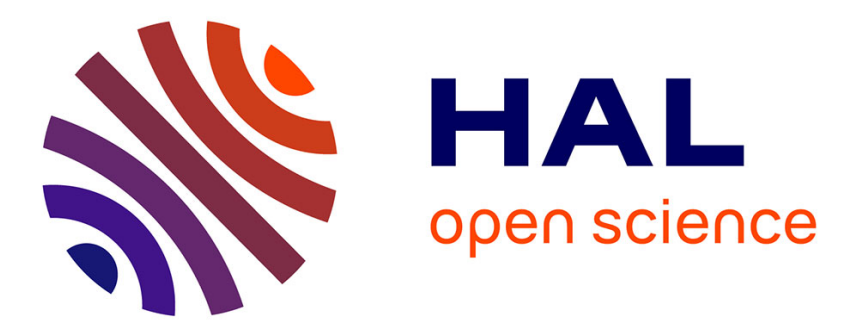

\title{
HONO Budget and Its Role in Nitrate Formation in the Rural North China Plain
}

Chaoyang Xue, Chenglong Zhang, Can Ye, Pengfei Liu, Valéry Catoire, Gisèle Krysztofiak, Hui Chen, Yangang Ren, Xiaoxi Zhao, Jinhe Wang, et al.

\section{- To cite this version:}

Chaoyang Xue, Chenglong Zhang, Can Ye, Pengfei Liu, Valéry Catoire, et al.. HONO Budget and Its Role in Nitrate Formation in the Rural North China Plain. Environmental Science and Technology, 2020, 54 (18), pp.11048-11057. 10.1021/acs.est.0c01832 . insu-02950517

\section{HAL Id: insu-02950517 https://hal-insu.archives-ouvertes.fr/insu-02950517}

Submitted on 15 Feb 2022

HAL is a multi-disciplinary open access archive for the deposit and dissemination of scientific research documents, whether they are published or not. The documents may come from teaching and research institutions in France or abroad, or from public or private research centers.
L'archive ouverte pluridisciplinaire HAL, est destinée au dépôt et à la diffusion de documents scientifiques de niveau recherche, publiés ou non, émanant des établissements d'enseignement et de recherche français ou étrangers, des laboratoires publics ou privés. 


\title{
1 HONO budget and its role in nitrate 2 formation in the rural North China Plain
}

\author{
3 Authors \\ 4 Chaoyang Xue ${ }^{1,2,9}$, Chenglong Zhang ${ }^{1,3}{ }^{3},{ }^{2}$, Can $\mathrm{Ye}^{1,9}$, Pengfei Liu $^{1,3,9}$, Valéry Catoire ${ }^{2}$, Gisèle \\ 5 Krysztofiak $^{2}$, Hui Chen ${ }^{4}$, Yangang Ren ${ }^{7}$, Xiaoxi Zhao ${ }^{1,9}$, Jinhe Wang ${ }^{8}$, Fei Zhang ${ }^{4}$, Chongxu Zhang ${ }^{8}$, \\ 6 Jingwei Zhang, ${ }^{9}$, Junling $\mathrm{An}^{9}{ }^{10}$, Tao Wang ${ }^{5}$, Jianmin $\mathrm{Chen}^{4}$, Jörg Kleffmann ${ }^{6}$, Abdelwahid \\ 7 Mellouki ${ }^{7,11}$, Yujing $\mathrm{Mu}^{1,3,9^{*}}$ \\ 8 Affiliation \\ 91 Research Centre for Eco-Environmental Sciences, Chinese Academy of Sciences, Beijing \\ 10100085 , China \\ 112 Laboratoire de Physique et Chimie de l'Environnement et de l'Espace (LPC2E), CNRS- \\ 12 Université Orléans-CNES, 45071 Orléans Cedex 2, France \\ 133 Centre for Excellence in Regional Atmospheric Environment, Institute of Urban Environment, \\ 14 Chinese Academy of Sciences, Xiamen 361021, China \\ 4 Shanghai Key Laboratory of Atmospheric Particle Pollution and Prevention, Department of \\ Environmental Science and Engineering, Institute of Atmospheric Sciences, Fudan University, \\ Shanghai 200438, China \\ 5 Department of Civil and Environmental Engineering, Hong Kong Polytechnic University, Hong \\ Kong, China \\ 6 Physical and Theoretical Chemistry, University of Wuppertal, Gaußstrasse 20, 42119 Wuppertal, \\ Germany \\ 7 Institut de Combustion Aérothermique, Réactivité et Environnement, Centre National de la \\ Recherche Scientifique (ICARE-CNRS), Observatoire des Sciences de l'Univers en région \\ Centre, CS 50060, 45071 cedex02, Orléans, France \\ 8 School of Municipal and Environmental Engineering, Co-Innovation Centre for Green Building \\ of Shandong Province, Shandong Jianzhu University, Jinan 250101, China \\ 9 University of Chinese Academy of Sciences, Beijing 100049, China \\ ${ }^{10}$ State Key Laboratory of Atmospheric Boundary Layer Physics and Atmospheric Chemistry \\ (LAPC), Institute of Atmospheric Physics (IAP), Chinese Academy of Sciences, Beijing 100029, \\ China \\ ${ }^{11}$ Environmental Research Institute, Shandong University, Jinan, Shandong, China \\ Corresponding to: Yujing Mu (yjmu@rcees.ac.cn)
}




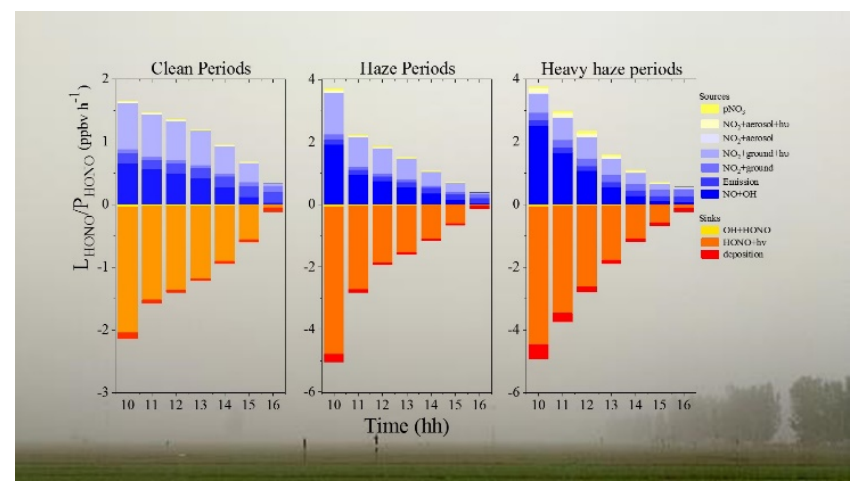

\section{Abstract}

Nitrous acid (HONO) is a major precursor of tropospheric hydroxyl radical $(\mathrm{OH})$ that accelerates the formation of secondary pollutants. The HONO sources, however, are not well understood, especially in polluted areas. Based on a comprehensive winter field campaign conducted at a rural site of the North China Plain, a box model (MCM v3.3.1) was used to simulate the daytime HONO budget and nitrate formation. We found that HONO photolysis acted as the dominant source for primary $\mathrm{OH}$ with a contribution of more than $92 \%$. The observed daytime HONO could be well explained by the known sources in the model. The heterogeneous conversion of $\mathrm{NO}_{2}$ on ground surfaces and the homogeneous reaction of $\mathrm{NO}$ with $\mathrm{OH}$ were the dominant $\mathrm{HONO}$ sources with contributions of more than $36 \%$ and $34 \%$ to daytime $\mathrm{HONO}$, respectively. The contribution from the photolysis of particle nitrate and the reactions of $\mathrm{NO}_{2}$ on aerosol surfaces were found to be negligible in clean periods $(2 \%)$ and slightly higher during polluted periods $(8 \%)$. The relatively high $\mathrm{OH}$ levels due to fast $\mathrm{HONO}$ photolysis at the rural site remarkably accelerated gas-phase reactions, resulting in the fast formation of nitrate as well as other secondary pollutants in the daytime.

\section{Introduction}

The hydroxyl radical $(\mathrm{OH})$ is the most important oxidant in the troposphere to initiate the oxidation of organic and inorganic compounds, leading to the formation of secondary pollutants such as ozone $\left(\mathrm{O}_{3}\right)$, secondary organic (SOA) and secondary inorganic aerosols (SIA), which deteriorate regional air quality ${ }^{1,2}$. Therefore, numerous field campaigns over the world have been conducted with the target to improve our understanding of radical chemistry, including the quantification of the sources and sinks of $\mathrm{OH}^{1,2}$. Nitrous acid (HONO) has been recognized as an important primary $\mathrm{OH}$ source to initiate daytime atmospheric photochemistry ${ }^{3}$. Recent studies found that HONO not only played a dominant role in triggering daytime atmospheric chemistry in the early morning but also acted as an important, even the dominant $\mathrm{OH}$ source throughout the whole day, e.g., the photolysis of HONO contributed ca. $20 \%-80 \%$ of atmospheric primary $\mathrm{OH}$ production in polluted regions ${ }^{4-8}$. Because the classic gas-phase reaction of $\mathrm{NO}$ with $\mathrm{OH}$ cannot explain the extremely high HONO levels 
observed in the daytime, additional HONO sources were further proposed based on laboratory studies and field campaigns including a) direct emission from combustion process ${ }^{9-13}$, b) $\mathrm{NO}_{2}$ heterogeneous reduction on various surfaces such as soil ${ }^{14,15}$, c) photosensitized $\mathrm{NO}_{2}$ heterogeneous reduction on the organic surfaces ${ }^{16,17}$, d) photolysis of total nitrate $\left(\mathrm{TNO}_{3}\right.$, the sum of nitric acid $\left(\mathrm{HNO}_{3}\right)$ and particle nitrate $\left.\left(\mathrm{pNO}_{3}\right)\right)^{18-20}$, e) soil abiotic or biotic emissions ${ }^{21,22}$ and f) other proposed HONO sources ${ }^{23}$. A detailed summary of HONO sources can be found in the Supplementary Information (SI). Several studies evaluated the relative contribution of each source to atmospheric HONO through the comparison between model simulations and the observations, indicating that atmospheric HONO in the daytime still could not be well explained in many polluted areas ${ }^{24-27}$.

The North China Plain (NCP) is suffering from severe particle/aerosol pollution (usually called haze pollution), especially in wintertime, and extremely high $\mathrm{HONO}$ concentrations were also frequently observed during the winter haze pollution events in the $\mathrm{NCP}^{28,29}$. For example, Li et al. ${ }^{28}$ reported an averaged noontime $\mathrm{HONO}$ mixing ratio of up to ca. $1.0 \mathrm{ppbv}$ under high particle concentrations in Ji'nan city (China). Zhang et al. ${ }^{29}$ found maximum and noontime HONO mixing ratios of 10.7 ppbv and ca. $1.4 \mathrm{ppbv}$ during haze pollution periods in the winter of Beijing, respectively. However, modeled and measured HONO levels were still not in agreement, e.g., noontime HONO levels in winter of Beijing were still underestimated by $50 \%$ even if the HONO sources of direct emission, $\mathrm{NO}_{2}$ heterogeneous reactions, and soil emission were taken into account in WRF-Chem models ${ }^{26,27}$. Particle nitrate in the winter of the NCP was recently found to be the major inorganic aerosol component with contribution comparable to or even larger than sulfate and showed a still increasing trend during the last decade ${ }^{30}$. Recent laboratory studies reported that photolysis of particle nitrate could lead to significant production of HONO with photolysis rates 2-3 orders of magnitude faster ${ }^{18,19}$ than the photolysis of pure $\mathrm{HNO}_{3}$ in the gas phase or adsorbed on clean glass surfaces ${ }^{31}$. In contrast, Romer et al. ${ }^{32}$ found that only moderate enhancements of 1-30 times faster are most consistent with the observations. Therefore, the exceptionally high concentration of particle nitrate during the haze period in winter of the NCP may also make a potential contribution to atmospheric HONO. However, up to now, no study evaluates the contribution of particle nitrate photolysis to atmospheric HONO in the NCP. Additionally, the high levels of daytime HONO during winter haze days in the NCP would significantly contribute to $\mathrm{OH}$ radicals that promote particle nitrate formation through the reaction of $\mathrm{NO}_{2}$ with $\mathrm{OH}^{33}$, whereas, the quantification of the contribution of $\mathrm{HONO}$ to $\mathrm{OH}$ and nitrate formation under haze conditions in the NCP is rarely reported ${ }^{6,8}$. In the present work, based on a comprehensive field campaign with measurements of various pollutants (HONO, VOCs, aerosols, etc.) and meteorological parameters during winter at a rural site of the NCP, a box model (MCM v3.3.1) was used to explore the HONO budget concerning the reported sources (i.e., homogeneous reaction, direct emission, $\mathrm{NO}_{2}$ reduction on aerosol and ground surfaces, and particle nitrate photolysis) and its contribution to radical and nitrate formation.

\section{Methods}

\section{Field measurements}

Field observation of HONO and related pollutants were conducted at the station of Rural Environmental, Chinese Academy of Sciences (SRE-CAS), located in Dongbaituo village ( $38^{\circ} 42^{\prime} \mathrm{N}$, 
$\left.115^{\circ} 15^{\prime} \mathrm{E}\right)$, Hebei province, China. The station was surrounded by agricultural fields planted with winter wheat. It's about $30 \mathrm{~km}$ in the southwest of Baoding city and $170 \mathrm{~km}$ to the southwest of Beijing. The nearest county seat, Wangdu, is about $10 \mathrm{~km}$ northwest to the station. The detailed information about the station has been well documented in our previous studies ${ }^{34}$. During the campaign from $3^{\text {rd }}$ to $24^{\text {th }}$ in December of 2017, a commercial LOPAP (QUMA, Model LOPAP-03) was used to measured HONO concentrations ${ }^{35,36}$. Instrument background signals were conducted by sampling ultrapure nitrogen at least twice per day, and single-point calibrations were carried out by diluted nitrite standard solution (Sigma-Aldrich) at least once per week. Intercomparison in the NCP between various HONO measurement techniques also confirmed the reliability of LOPAP to quantify $\mathrm{HONO}$ in the polluted regions. ${ }^{34,36,37}$ Other instruments for key-related species (VOCs, OVOCs, $\mathrm{NO}, \mathrm{NO}_{2}, \mathrm{NH}_{3}, \mathrm{O}_{3}, \mathrm{H}_{2} \mathrm{O}_{2}, \mathrm{CO}, \mathrm{PM}_{2.5}$, particle size distribution, and composition, etc.) and meteorological parameters (pressure, temperature, relative humidity $(\mathrm{RH}), \mathrm{J}\left(\mathrm{NO}_{2}\right)$, etc.) are summarized in Table S1. The external sampling unit of LOPAP and inlets of other instruments were installed about $3.4 \mathrm{~m}$ above the ground level. The distance between every two inlets or sampling units were less than $20 \mathrm{~m}$. Note that $\mathrm{NO}_{2}$ measured by chemiluminescent technology used in this campaign may overestimate ambient $\mathrm{NO}_{2}$ by the interference from $\mathrm{HONO}, \mathrm{HNO}_{3}$, etc., and the validation of $\mathrm{NO}_{2}$ was therefore conducted in section 3 of the SI.

\section{Model description}

A 0-D box model MCM v3.3.1 $1^{38}$ was used to simulate the radical concentration and budget, the $\mathrm{HONO}$ budget, and the potential particle nitrate formation rate, $\mathrm{P}\left(\mathrm{HNO}_{3}\right)$, from gas-phase reaction $\mathrm{NO}_{2}+\mathrm{OH}$. The chemical mechanistic information was taken from the MCM v3.3.1 website (http://mcm.leeds.ac.uk/MCM) as the basic mechanism for the simulation. The model was run from $3^{\text {rd }}$ to $24^{\text {th }}$ December 2017 with a time step resolution of 1 hour and initiated by a 2-day spin-up for the first day. All the photolysis frequencies, except $\mathrm{J}\left(\mathrm{NO}_{2}\right)$ were calculated by the model and were scaled by the ratio measured to modeled $\mathrm{J}\left(\mathrm{NO}_{2}\right)$. More details about the model are shown in the SI. Although atmospheric $\mathrm{OH}$ concentration is essential for the HONO budget analysis, unfortunately, no radical measurements were available during this campaign. Therefore, we run the model with constraints on all measured parameters (case name: with $\mathrm{HONO}$ ) to simulate the $\mathrm{OH}$ concentrations. The simulated $\mathrm{OH}$ concentrations and budget were comparable with other winter measurements of $\mathrm{OH}$ (Figure S1-S3 and Section 1.2 in the SI). To reveal the contribution of atmospheric HONO to $\mathrm{OH}$ concentration and $\mathrm{P}\left(\mathrm{HNO}_{3}\right)$, another case with the constraints on all the measured parameters but without HONO (case name: without HONO) was also conducted. Then we parameterized the proposed HONO sources and added each of them in the basic mechanism separately for sensitivity tests. Briefly, Table 1 summarizes the model configuration for HONO simulations, of which 10 model scenarios from S-0 to S- 9 were set. The scenario S-0 was the base case, which only contained the default $\mathrm{HONO}$ source $\mathrm{NO}+\mathrm{OH}$. Scenarios from S-1 to S-6 were to test the sensitivity of each HONO source including direct emission, the dark $\mathrm{NO}_{2}$ uptake on ground surfaces, the dark $\mathrm{NO}_{2}$ uptake on aerosol surfaces, the photosensitized $\mathrm{NO}_{2}$ uptake on ground surfaces, the photosensitized $\mathrm{NO}_{2}$ uptake on aerosol surfaces, and the photolysis of particle nitrate. For the photolysis frequency of $\mathrm{pNO}_{3}, \mathrm{~J}\left(\mathrm{pNO}_{3}\right)$, the same diurnal shape as the gas-phase photolysis of $\mathrm{HNO}_{3}\left(\mathrm{~J}\left(\mathrm{HNO}_{3}\right)\right)$ was assumed ${ }^{39}$. Therefore, an enhancement factor $\left(\mathrm{EF}=\mathrm{J}\left(\mathrm{pNO}_{3}\right) / \mathrm{J}\left(\mathrm{HNO}_{3}\right)\right)$ due to faster particle nitrate photolysis than gas-phase $\mathrm{HNO}_{3}$ was deployed in the model to characterize the photolysis of particle 
nitrate as well as the HONO production. For the sensitivity tests, a typical parameter (emission ratio for direct emission, $\mathrm{NO}_{2}$ uptake coefficients for heterogeneous reaction and $\mathrm{EF}$ for particle nitrate) and the upper/lower limit for each source were scaled by the proposed larger/smaller parameters or a variation factor (see the SI, Section 2).

The photosensitized heterogeneous reaction of $\mathrm{NO}_{2}$ on ground surfaces has been proved to have a significant impact on HONO budget $\mathrm{t}^{25,40-45}$, especially for ground base measurements like this study with a sampling height $(3.4 \mathrm{~m}$ ) close to the ground source. However, the impact may depend on the $\mathrm{NO}_{2}$ levels, e.g., recent laboratory studies found that the photo-enhanced uptake coefficient of $\mathrm{NO}_{2}$ on surfaces remarkably slowed down with increasing $\mathrm{NO}_{2}$ concentration ${ }^{16,17}$. Considering atmospheric $\mathrm{NO}_{2}$ concentrations at the sampling site were usually high, i.e., averaged $\mathrm{NO}_{2}$ was about $20 \pm 10,29 \pm 12$, and $39 \pm 14$ ppbv in CP, HP and HHP, respectively, two additional scenarios S8 and S- 9 with reducing photosensitized $\mathrm{NO}_{2}$ uptake coefficients by $30 \%$ and $60 \%$ were also tested.

Table 1. Configurations of the model simulations for different HONO source scenarios. $\alpha$ : the emitted ratio of $\mathrm{HONO}$ to $\mathrm{NO}_{\mathrm{x}}$ for direct emission; $\mathrm{EF}$ : enhancement factor of the photolysis frequency of particle nitrate compared to that of gas-phase $\mathrm{HNO}_{3}\left(\mathrm{EF}=\mathrm{J}\left(\mathrm{pNO}_{3}\right) / \mathrm{J}\left(\mathrm{HNO}_{3}\right)\right)$. From S-1 to S-6, sensitivity tests on the sources were conducted with the corresponding parameters scaled by the typically used, the lower limit, and the upper limit values (see details in the SI).

$\begin{array}{ll}\text { Scenarios } & \text { Configuration } \\ \text { S-0 } & \mathrm{NO}+\mathrm{OH}+\mathrm{M} \rightarrow \mathrm{HONO}+\mathrm{M} \\ \text { S-1 } & \mathrm{S}-0+\text { direct emission }(\alpha=0.8 \%, 0.3 \%, 1.6 \%)^{9-12} \\ \text { S-2 } & \mathrm{S}-0+\text { dark } \mathrm{NO}_{2} \text { uptake on ground surfaces }\left(\gamma_{1}=1 \times 10^{-6}, 0.2 \times 10^{-6}, 5 \times 10^{-6}\right)^{14-17} \\ \text { S-3 } & \text { S-0 }+ \text { dark } \mathrm{NO}_{2} \text { uptake on aerosol surfaces }\left(\gamma_{1}=1 \times 10^{-6}, 0.2 \times 10^{-6}, 5 \times 10^{-6}\right)^{14-17} \\ \text { S-4 } & \text { S-0 }+ \text { photosensitized } \mathrm{NO}_{2} \text { uptake on ground surfaces }\left(\gamma_{2}=1.35 \times 10^{-5}, 0.27 \times 10^{-5},\right. \\ & \left.6.75 \times 10^{-5}\right)^{14-17} \\ \text { S-5 } & \text { S-0 }+ \text { photosensitized } \mathrm{NO}_{2} \text { uptake on aerosol surfaces }\left(\gamma_{2}=1.35 \times 10^{-5}, 0.27 \times 10^{-5},\right. \\ & \left.6.75 \times 10^{-5}\right)^{14-17} \\ \text { S-6 } & \text { S-0 }+ \text { photolysis of particle nitrate }(\mathrm{EF}=30,1,100)^{18-20,31,32} \\ \text { S-7 } & \text { S-0 }+ \text { all the tested sources } \\ \text { S-8 } & \text { S-7 with } 0.7 \times \gamma_{2} \\ \text { S-9 } & \text { S-7 with } 0.4 \times \gamma_{2}\end{array}$




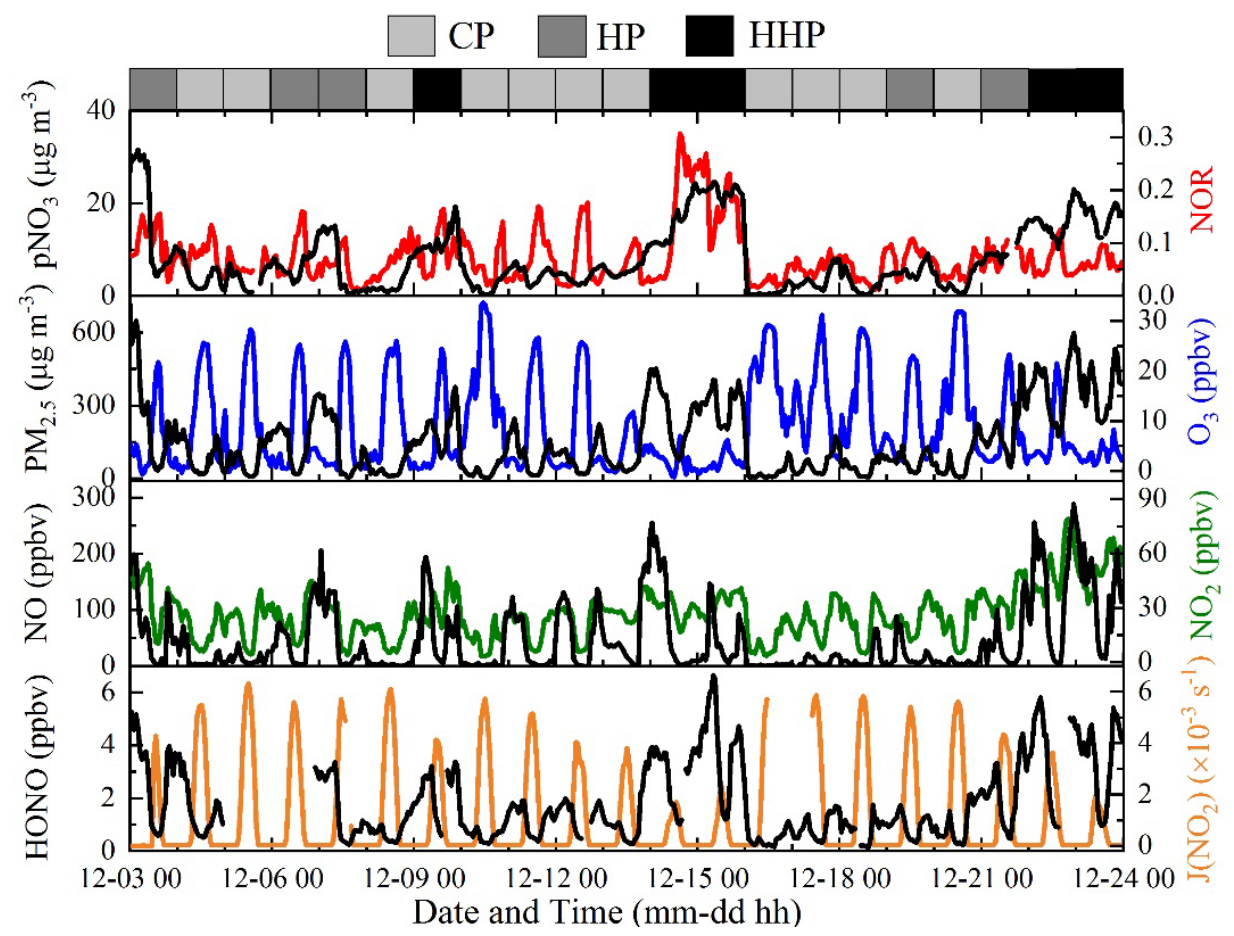

Figure 1. Time series of HONO and related parameters measured during the campaign. The light gray, dark gray, and black areas on the top part represent the pollution levels of the clean periods (CP), haze periods (HP), and heavy haze periods (HHP), respectively. On the left axis, HONO, NO, $\mathrm{PM}_{2.5}$, and $\mathrm{pNO}_{3}$ (particle nitrate) are shown in black lines in each layer from bottom to the top. $\mathrm{J}\left(\mathrm{NO}_{2}\right)$ (photolysis frequency of $\mathrm{NO}_{2}$ ), $\mathrm{NO}_{2}, \mathrm{O}_{3}$, and $\mathrm{NOR}$ (nitrogen oxidation ratio) are shown in yellow, green, blue, and red lines on the right axis, respectively.

Time series of $\mathrm{HONO}$, particulate matter with a diameter of less than $2.5 \mu \mathrm{m}\left(\mathrm{PM}_{2.5}\right)$, particle nitrate $\left(\mathrm{pNO}_{3}\right), \mathrm{NO}, \mathrm{NO}_{2}, \mathrm{O}_{3}$, photolysis frequency of $\mathrm{NO}_{2}\left(\mathrm{~J}_{\left.\left(\mathrm{NO}_{2}\right)\right)}\right)$ and $\mathrm{NOR}$ (nitrogen oxidation ratio, $\left.N O R=\frac{n \mathrm{NO}_{3}^{-}}{n \mathrm{NO}_{3}^{-}+n \mathrm{NO}_{2}}\right)^{46}$ are shown in Figure 1. The air temperature (Temp), relative humidity (RH) particle surface area density (PS), and ammonia mixing ratios $\left(\mathrm{NH}_{3}\right)$ are illustrated in Figure $\mathrm{S} 4$. Air pollution at this rural site was severe, e.g., the hourly levels of $\mathrm{PM}_{2.5}$ and $\mathrm{NO}_{\mathrm{x}}\left(\mathrm{NO}+\mathrm{NO}_{2}\right)$ frequently exceeded $100 \mu \mathrm{g} \mathrm{m}^{-3}$ and $100 \mathrm{ppbv}$, respectively. Campaign averaged levels of $\mathrm{HONO}, \mathrm{PM}_{2.5}, \mathrm{pNO}_{3}$, $\mathrm{NO}$, and $\mathrm{NO}_{2}$ were $1.8 \pm 1.4 \mathrm{ppbv}, 98 \pm 112 \mu \mathrm{g} \mathrm{m}^{-3}, 8.0 \pm 7.0 \mu \mathrm{g} \mathrm{m}^{-3}, 45 \pm 62 \mathrm{ppbv}$ and $27 \pm 14 \mathrm{ppbv}$, respectively. In particular, the averaged daytime (7:00-17:00 local time) HONO mixing ratio at this site could achieve as high as $1.3 \pm 1.3 \mathrm{ppbv}$, which was remarkably higher than those observed in European or American cities ${ }^{47-49}$, but comparable to those observed in the $\mathrm{NCP}^{29}$ and Santiago de Chile ${ }^{5}$ (Table S2). The averaged daytime $\mathrm{HONO} / \mathrm{NO}_{\mathrm{x}}$ ratio was $3.3 \% \pm 1.7 \%$ which was much higher than those from direct emission (0.3\%-1.6\% $)^{9-12}$, suggesting atmospheric HONO at the rural site 
longer lifetime of $\mathrm{NO}_{\mathrm{x}}$ than $\mathrm{HONO}$ during the daytime. The relatively high levels of $\mathrm{HONO}$ at the rural site were suspected to be the dominant source for atmospheric $\mathrm{OH}$, and thus played an essential role in the formation of secondary pollutants, e.g., evident and frequent increase of $\mathrm{NOR}$ and $\mathrm{pNO}_{3}$ concentrations during the daytime could be identified in Figure 1.

To better understand the daytime sources for HONO, as well as the interaction between HONO and nitrate, the field data were classified into three classes: clean periods (CP, 11 days) when the averaged $\mathrm{PM}_{2.5}$ concentrations during daytime were below $50 \mu \mathrm{g} \mathrm{m}^{-3}$, haze periods (HP, 5 days) when $\mathrm{PM}_{2.5}$ concentrations were in the range of 50-150 $\mu \mathrm{g} \mathrm{m}^{-3}$ and heavy haze periods (HPP, 5 days) when $\mathrm{PM}_{2.5}$ concentrations were above $150 \mu \mathrm{g} \mathrm{m}^{-3}$. The averaged diurnal variations and concentrations of HONO and related parameters during different pollution periods are shown in Figure S5 and Table S3. Daytime HONO increased by a factor of 3 during the HPP to the CP, while the solar intensity only decreased by a factor of 2 . Therefore, the $\mathrm{OH}$ production rate through $\mathrm{HONO}$ photolysis was expected to be larger in the HPP. Besides, $\mathrm{NO}_{2}$ during the HPP also increased by a factor of 3 to the $\mathrm{CP}$, which would promote the reaction of $\mathrm{NO}_{2}$ with $\mathrm{OH}$, leading to the faster daytime particle nitrate formation during the HHP. Furthermore, the exceptionally high mixing ratios of HONO precursors, including $\mathrm{NO}_{\mathrm{x}}$ and particle nitrate during the HHP might also accelerate $\mathrm{HONO}$ formation through the heterogeneous reactions of $\mathrm{NO}_{\mathrm{x}}$ or photolysis of particle nitrate, resulting in a remarkable increase of HONO during HPP.

\section{HONO simulation and budget}

Model results from the base case (S-0) and sensitivity tests on each HONO source (S-1 to S-6) are shown in Figure S6 and S7. The default HONO source, the homogeneous reaction of NO with $\mathrm{OH}$ (S-0), was not able to explain the observations (Figure S6), suggesting additional daytime HONO sources. With the presence of direct emission (S-1), the dark heterogeneous reactions of $\mathrm{NO}_{2}$ on the ground surfaces (S-2) or aerosol surfaces (S-3), the modeled daytime HONO was still much lower than the observations (Figure S6). However, the model could well reproduce the observations during most of the daytime (from 10:00 to 15:00) when a median value of the uptake coefficient was adopted for the photosensitized heterogeneous reaction of $\mathrm{NO}_{2}$ on ground surfaces, and the upper and lower limits could well cover the observations in the three periods (Figure S7, A to C), indicating the possible important role of photosensitized heterogeneous reaction of $\mathrm{NO}_{2}$ on ground surfaces in daytime HONO formation. In contrast, both the photo-enhanced sources of the photosensitized heterogeneous reaction of $\mathrm{NO}_{2}$ on aerosol surfaces and the photolysis of particle nitrate showed a negligible impact on daytime HONO formation even when the uptake coefficient or EF were enlarged (Figure S7, D to I). The large difference for the sensitivities between the photosensitized heterogeneous reactions of $\mathrm{NO}_{2}$ on ground surfaces and particle surfaces was mainly ascribed to the much larger $\mathrm{S} / \mathrm{V}$ ratio of ground surfaces than that of particle surfaces (e.g., an average of $1.2 \times 10^{-3}$ $\mathrm{m}^{-1}$ in this study $4^{44,50,51}$ with the similar $\mathrm{NO}_{2}$ uptake kinetics on particle and ground surfaces.

Figure 2 shows the model results of scenarios from S-7 to S-9 with inputting all the additional sources. With the typical photosensitized $\mathrm{NO}_{2}$ uptake coefficient on the ground surfaces (S-7), the model could well reproduce the observed daytime HONO ( $0.9 \%$ overestimation) during the $\mathrm{CP}$ (Figure 2A), but distinctly overestimated HONO during the HP and HHP (Figure 2B and C). In the scenario S-8, the photosensitized $\mathrm{NO}_{2}$ uptake coefficient was reduced by $30 \%$, for which modeled HONO was much closer to the observation (3.6\% underestimation) during the HP (Figure 2E) but 
still higher than the observations during the HHP (Figure 2F). The observed HONO during the HHP could be partially reproduced when the photosensitized $\mathrm{NO}_{2}$ uptake coefficient was reduced by another 30\% in S-9 (Figure 2I). The modeled HONO in S-9 could well explain the observation in the morning and noontime (10:00-15:00, 1.7\% underestimation) but still underestimated HONO in the late afternoon (32.5\% underestimation), which was perhaps caused by an overestimation of MLH or the relative small dark $\mathrm{NO}_{2}$ uptake coefficient on the ground surfaces, leading to the underestimation of ground $\mathrm{HONO}$ formation. With a larger dark $\mathrm{NO}_{2}$ uptake coefficient on the ground surfaces during the sensitivity tests, the model could well reproduce the observed HONO (Figure S6F), which may act as evidence that the dark $\mathrm{NO}_{2}$ uptake on the ground surfaces was underestimated in the afternoon of HHP.
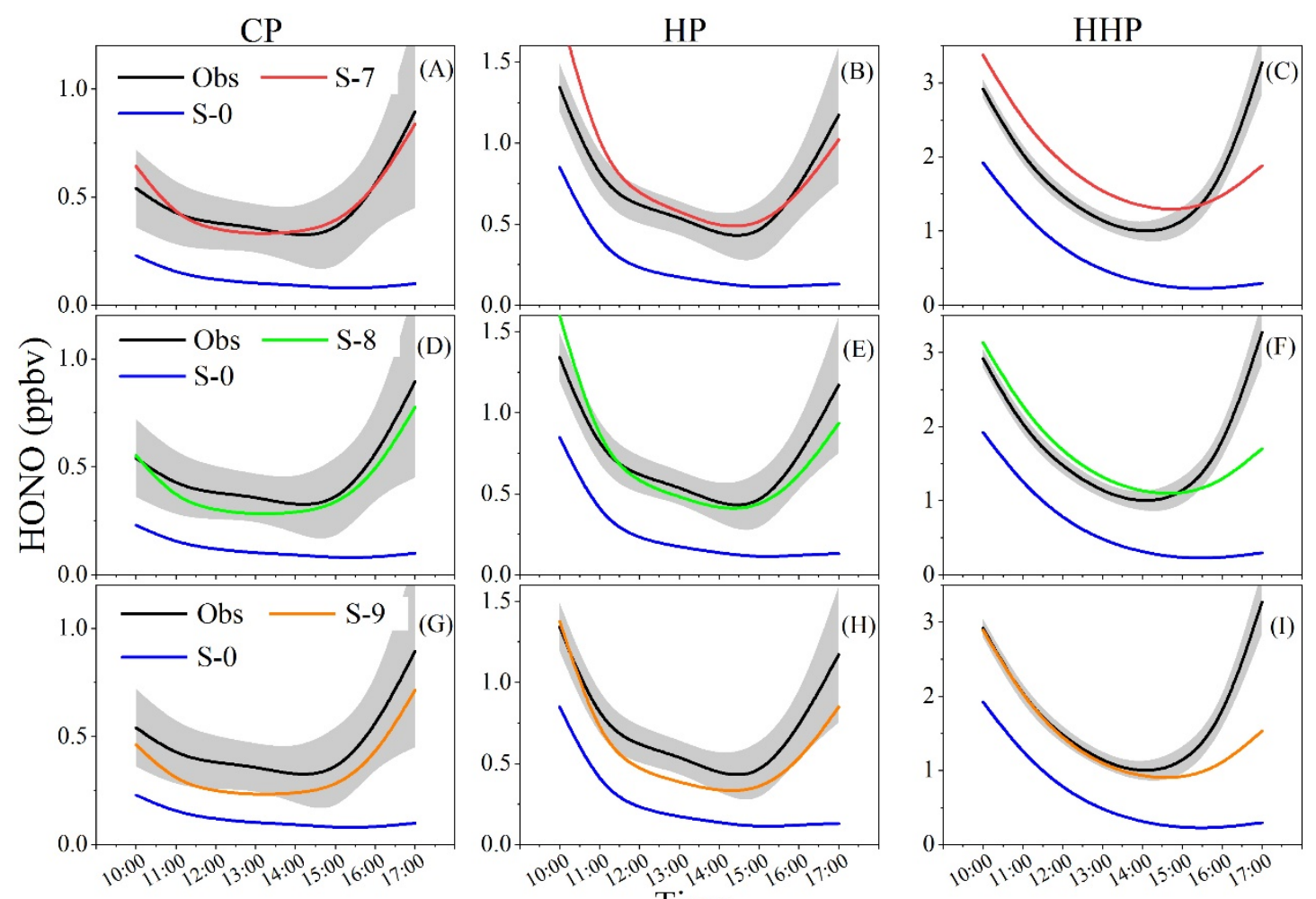

Time

Figure 2. Model results of diurnal profiles of simulated and observed daytime HONO during different periods (CP: clean periods, HP: haze periods, HHP: heavy haze periods). Throughout the whole graph, the black lines represent the observed average diurnal HONO variation with the standard deviation as the shaded area. The blue lines represent the model HONO mixing ratios in the base case S- 0 . The red, green and orange lines represent the model HONO results in the case S7, S-8 and S-9, respectively. Similar to the observation, all the model results were classified into three periods to assess the model performance during different pollution periods.

With gradually reducing the photosensitized $\mathrm{NO}_{2}$ uptake coefficients, model performance on $\mathrm{HONO}$ simulations for the polluted periods (HP and HHP) was largely improved, which suggests that the $\mathrm{NO}_{2}$ uptake coefficients depended on the pollution levels of $\mathrm{NO}_{2}$ as observed in laboratory studies $^{16,17}$. Although in some model studies the uptake coefficients were already scaled by RH and light intensity ${ }^{50,52}$ leading to a significant improvement to explore the HONO budget and the SOA formation ${ }^{33,52}$, etc., the still existing differences between observations and simulations are possibly 
caused by the missing parameterization of the $\mathrm{NO}_{2}$ uptake kinetics by the pollution levels as discussed in the present study for the first time. The observed HONO in different pollution periods was well reproduced by the model, implying that more similar analysis is still necessary to better understand HONO formation by the models in the polluted areas like the NCP.
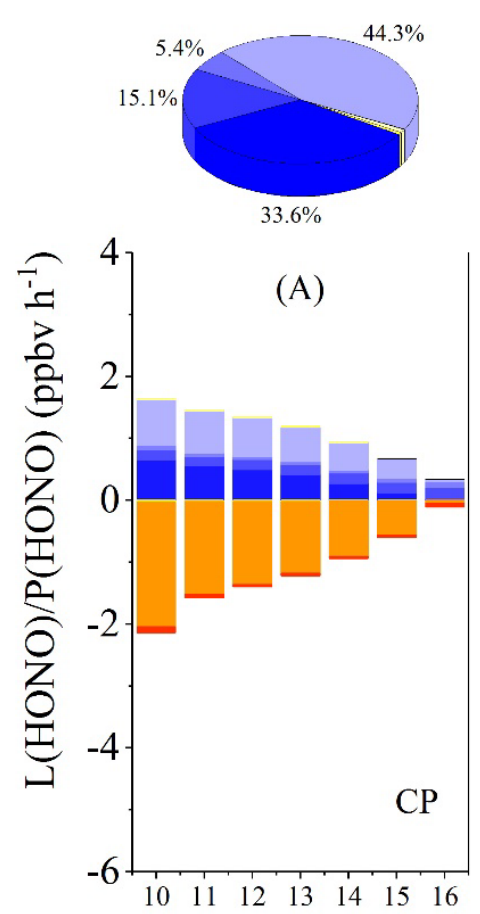

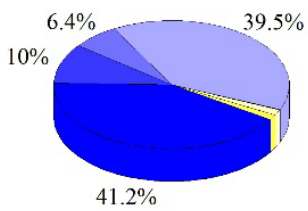

(B)

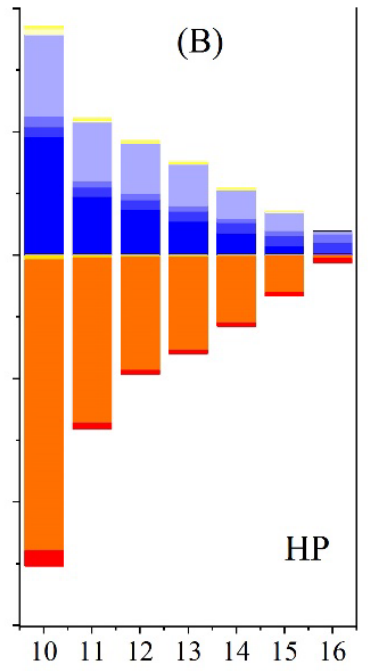

Time (hh)
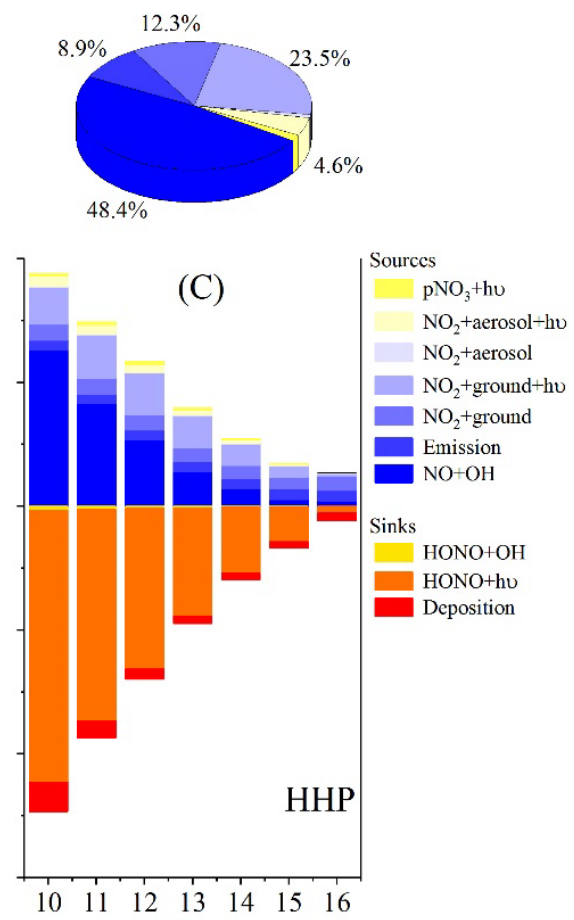

Figure 3. Diurnal HONO budget and the relative contribution from each source during different periods (CP: clean periods, HP: haze periods, HHP: heavy haze periods). The histograms and the pie charts contain the HONO source (positive) and sink (negative) strengths, and the corresponding relative contributions from each HONO source. The pie charts show the averaged relative contribution of each HONO source to HONO formation (10:00-17:00) during CP, HP, and HHP, respectively. Only the contribution larger than $2 \%$ is marked in the pie charts.

The diurnal HONO budget and the relative contribution from each source during each period are shown in Figure 3. Apparently, the total HONO sink strength was slightly larger than the total source strength in the daytime, which was consistent with the daytime decreasing trend of the observed HONO. Among the six HONO sources, the homogeneous HONO formation from the gas phase reaction of $\mathrm{NO}+\mathrm{OH}$ always acted as one of the essential sources for $\mathrm{HONO}$, accounting for $33.6 \%$, $41.2 \%$ and $48.4 \%$ of daytime HONO formation during the CP, HP, and HHP, respectively. The significant increase of the contribution for the gas phase reaction to atmospheric HONO from the $\mathrm{CP}$ to the HHP was mainly ascribed to the remarkable increase of daytime NO, e.g., the NO concentration increased by a factor of ca. 7 from the CP to the HHP (Table S3) while the $\mathrm{OH}$ concentration only declined by a factor of less than 3 (Figure 5). Additionally, the reaction of $\mathrm{NO}+\mathrm{OH}$ made a more significant contribution to $\mathrm{HONO}$ at noontime during the $\mathrm{CP}$ and in the early morning during the HP and HHP (Figure S8), which could be explained by the relatively high $\mathrm{OH}$ concentrations at noontime during the $\mathrm{CP}$ (Figure 5) and the relatively high NO in the early morning during the HP and HHP (Figure S5). The significant contribution from the homogeneous formation 
of HONO was also found at other high- $\mathrm{NO}_{\mathrm{x}}$ sites such as London ${ }^{47}$, Beijing ${ }^{8,53}$, Tai $\mathrm{Wan}^{54}$, and Santiago de Chile ${ }^{55}$. Nevertheless, the formation of HONO by this gas-phase reaction does not represent a net $\mathrm{OH}$ source, since the same quantity of $\mathrm{OH}$ radicals is consumed compared to the $\mathrm{OH}$ formation by the subsequent HONO photolysis. Thus, for the future, additional measurements of $\mathrm{OH}$ radical concentrations are recommended to better quantify net $\mathrm{OH}$ initiation by HONO photolysis. In contrast to the gas phase reaction of $\mathrm{NO}+\mathrm{OH}$, the contribution of the photosensitized heterogeneous reactions of $\mathrm{NO}_{2}$ on ground surfaces to atmospheric $\mathrm{HONO}$ exhibited a declining trend from the CP to the HPP, with the contributions of $44.3 \%, 39.5 \%$ and $23 \%$ during the CP, HP, and HPP, respectively. The contribution of the dark heterogeneous reaction of $\mathrm{NO}_{2}$ on the ground surfaces to atmospheric $\mathrm{HONO}$ increased with increasing $\mathrm{NO}_{2}$ concentrations from the $\mathrm{CP}$ to the HHP, with a contribution of $5.4 \%$ in the $\mathrm{CP}, 6.4 \%$ in the HP and $12.3 \%$ in the HHP. The proportion of the direct $\mathrm{HONO}$ emission to the total daytime HONO formation gradually decreased from $15.1 \%$ in the $\mathrm{CP}$ to $10 \%$ in the HP and $8.9 \%$ in the HHP, which was mainly ascribed to the significant increase of $\mathrm{HONO}$ source from the gas phase reaction of $\mathrm{NO}$ with $\mathrm{OH}$. Both the dark heterogeneous reaction and the photosensitized heterogeneous reaction of $\mathrm{NO}_{2}$ on aerosol surfaces made small contributions to $\mathrm{HONO}$ formation, with the largest contribution of about $4.6 \%$ during HHP when both aerosol and $\mathrm{NO}_{2}$ concentrations were very high, which is in agreement with previous studies ${ }^{50,56}$. Although the photolysis of $\mathrm{pNO}_{3}$ has been proposed as one important source for atmospheric $\mathrm{HONO}$, the contribution from $\mathrm{pNO}_{3}$ photolysis to $\mathrm{HONO}$ formation was found to be negligible $(<2 \%)$ even during the $\mathrm{HHP}$ with high $\mathrm{pNO}_{3}$ concentrations. As discussed before, the photolysis of $\mathrm{pNO}_{3}$ was not sensitive to $\mathrm{EF}$ values in the range of 1 to 100 and the modeled HONO in S-6 was much lower than the observation (Figure S7), suggesting that the photolysis of $\mathrm{pNO}_{3}$ is not expected to play an important role in the HONO budget during wintertime at high- $\mathrm{NO}_{\mathrm{x}}$ polluted regions such as the rural NCP in this study.

The HONO loss through photolysis was the major sink, accounting for more than $90 \%$ of the HONO loss during the daytime. The reaction of $\mathrm{HONO}+\mathrm{OH}$ contributed ca. $3.5 \%$ to the $\mathrm{HONO}$ loss during the $\mathrm{CP}, 1.5 \%$ during the HP and $1.4 \%$ during the HHP because of the relatively higher $\mathrm{OH}$ during the CP than the HP and HHP (Figure 5). In contrast, the deposition contributed to more significant loss of HONO during the HHP (9\%) than the $\mathrm{CP}(3 \%)$ and the HP (5\%) because of the relatively higher HONO concentrations during HHP than CP and HP (Figure S5).

Based on HONO budget results, the photosensitized heterogeneous reaction of $\mathrm{NO}_{2}$ on ground surfaces played an important role in the HONO budget, suggesting a vertical distribution of HONO. A rough estimation of the vertical distribution (Figure S9) calculated based on atmospheric turbulence (see details in SI) indicates that in the upper boundary layer, the role of HONO was expected to be less important than that at ground level, but may still significant, especially in polluted periods. Gradient HONO measurements should be conducted in the NCP to better quantify the impact of $\mathrm{HONO}$ on $\mathrm{HO}_{\mathrm{x}}$ chemistry in the atmospheric boundary layer ${ }^{57}$ and regional air pollution such as $\mathrm{O}_{3}$, SOA, and nitrate pollution. The aerosol-derived HONO sources, including heterogeneous reactions on aerosol surfaces and the photolysis of $\mathrm{pNO}_{3}$, did not make a significant contribution to HONO formation. High EFs could increase the HONO formation from $\mathrm{pNO}_{3}$ photolysis but should be carefully considered in model studies. More detailed, perhaps in-situ research at ambient conditions ${ }^{32}$, especially in the high $\mathrm{NO}_{\mathrm{x}}$ and high nitrate polluted areas, e.g., the $\mathrm{NCP}$ and other similar regions, are recommended. 
To explore the role of $\mathrm{HONO}$ in radical formation, we summarized the net primary $\mathrm{OH}$ production from five sources in the model, i.e., $\mathrm{HONO}$ photolysis (subtracted by the $\mathrm{OH}$ loss through $\mathrm{NO}+$ $\mathrm{OH}$ and $\mathrm{HONO}+\mathrm{OH}), \mathrm{O}_{3}$ photolysis, $\mathrm{HCHO}$ photolysis $\left(\mathrm{HCHO} \rightarrow \mathrm{H} / \mathrm{HCO} \rightarrow \mathrm{HO}_{2} \rightarrow \mathrm{OH}\right.$, here only primary emitted $\mathrm{HCHO}(37 \%)$ was considered), $\mathrm{H}_{2} \mathrm{O}_{2}$ photolysis, and ozonolysis of alkenes. The diurnal net $\mathrm{OH}$ production rate, $\mathrm{P}(\mathrm{OH})$, from each source, and its corresponding contribution to the total daytime $\mathrm{OH}$ production during each pollution period are shown in Figure 4. It is apparent that the net $\mathrm{OH}$ production from $\mathrm{HONO}$ photolysis, $\mathrm{P}(\mathrm{OH})_{\mathrm{HONO}}$, net, was always more than one order of magnitude larger than those from the other four sources, especially in the morning when $\mathrm{P}(\mathrm{OH})_{\mathrm{HONO}}$, net was 2-3 orders of magnitude larger than others, dominating the total $\mathrm{OH}$ initiation. As a result, $\mathrm{P}(\mathrm{OH})_{\mathrm{HONO}}$, net maintained at a high level (between $10^{6}-10^{7}$ molecules $\mathrm{cm}^{-3} \mathrm{~s}^{-1}$ ) and played the most important role in $\mathrm{OH}$ formation throughout the daytime. Compared to the $\mathrm{CP}$, the solar radiation during the HHP decreased by a factor of 2 (Figure S5E). However, $\mathrm{P}(\mathrm{OH})_{\mathrm{HONO}}$, net during the HHP was comparable to or even larger than that during the CP (Figure 4), which was because of the increase of $\mathrm{HONO}$ by a factor of about 3 (Figure S5A). The mean daytime primary $\mathrm{OH}$ production rates were $5.6 \times 10^{6}, 8.0 \times 10^{6}$ and $7.0 \times 10^{6}$ molecules $\mathrm{cm}^{-3} \mathrm{~s}^{-1}$ during CP, HP, and HHP, respectively, which were comparable to winter measurements in Weld Country ${ }^{4}$, Santiago de Chile ${ }^{5}$, and suburban Beijing ${ }^{6}$, and also to some summer measurements at this place ${ }^{7}$, etc. The daytime $\mathrm{OH}$ radical concentrations (Figure $\mathrm{S} 1$ ), however, were much lower than those in summer measurements, suggesting much higher $\mathrm{OH}$ reactivity $\left(\mathrm{k}_{\mathrm{OH}}\right)^{4-8}$ from the elevated levels of atmospheric pollutants including $\mathrm{NO}_{\mathrm{x}}$ (Figure 1 and Figure S4) and VOCs, leading to enhanced formation of secondary pollutants (e.g., nitrate and SOA, etc.).

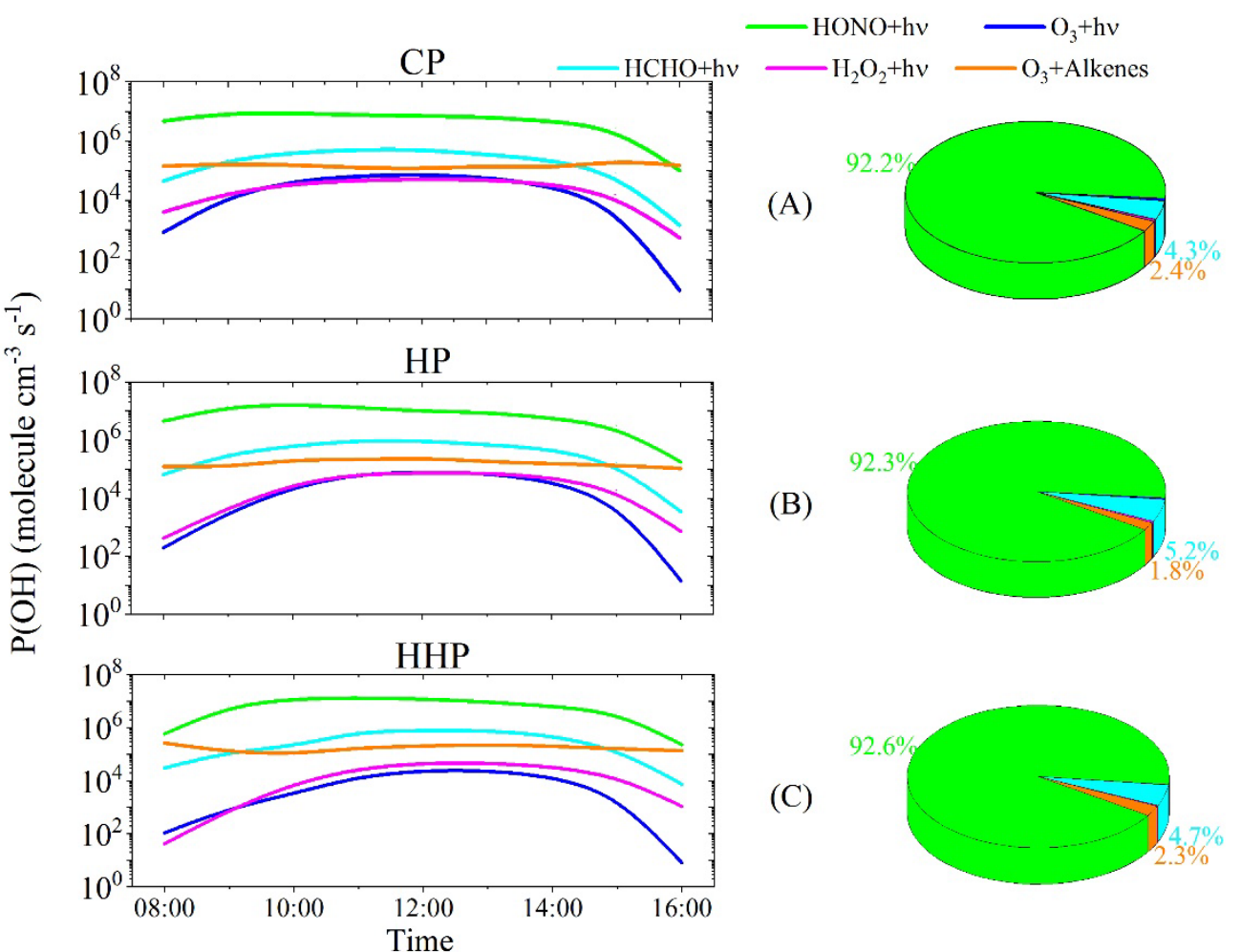

Figure 4. Modeled net $\mathrm{OH}$ production rates from five sources and their corresponding relative 11 
contribution. The colors of green, blue, cyan-blue, pink and orange represent the net primary $\mathrm{OH}$ production from $\mathrm{HONO}$ photolysis, $\mathrm{O}_{3}$ photolysis, $\mathrm{HCHO}$ photolysis, $\mathrm{H}_{2} \mathrm{O}_{2}$ photolysis and the ozonolysis of alkenes $\left(\mathrm{O}_{3}+\right.$ Alkenes), respectively. Both the contribution of $\mathrm{O}_{3}$ photolysis and $\mathrm{H}_{2} \mathrm{O}_{2}$ photolysis is less than $2 \%$ during the three periods. Note that net primary $\mathrm{OH}$ production from HONO was the production of $\mathrm{OH}$ through HONO photolysis subtracted by the $\mathrm{OH}$ loss through $\mathrm{NO}+\mathrm{OH}$ and $\mathrm{HONO}+\mathrm{OH}$. Only direct emitted $\mathrm{HCHO}$ could produce net primary $\mathrm{OH}$ $\left(\mathrm{HCHO} \rightarrow \mathrm{H} / \mathrm{HCO} \rightarrow \mathrm{HO}_{2} \rightarrow \mathrm{OH}\right)$ and the contribution of direct $\mathrm{HCHO}$ emission to the observation was $37 \%$ during the campaign estimated by multiple linear regression between $\mathrm{HCHO}, \mathrm{CO}$ (indicator for direct emission) and $\mathrm{O}_{3}$ (indicator for secondary formation).

Throughout the whole campaign, the contribution to the total primary $\mathrm{OH}$ production from HONO photolysis was about $92 \%$ (Figure 4). To the best of our knowledge, the largest contribution of HONO to OH reported by previous non-polar ${ }^{58}$ studies was $80.4 \%$ with $\mathrm{P}(\mathrm{OH})_{\mathrm{HONO}}$, net of $3.1 \times 10^{6}$ molecules $\mathrm{cm}^{-3} \mathrm{~s}^{-1}$ in Weld Country, Colorado ${ }^{4}$, both of which are, however, much lower than those in this study, suggesting a higher oxidizing capacity and more active photochemistry in the winter at this site. The second-largest primary $\mathrm{OH}$ source was the photolysis of $\mathrm{HCHO}$ and its contribution was always between $4 \%-5 \%$, which was because of the adverse trends of $\mathrm{HCHO}$ concentrations (low values during $\mathrm{CP}$ and high values during HHP) and photolysis frequency (high values during $\mathrm{CP}$ and low values during HHP) during the three periods. Compared to HONO photolysis, the ozonolysis of alkenes, $\mathrm{O}_{3}$ photolysis or $\mathrm{H}_{2} \mathrm{O}_{2}$ photolysis made a negligible contribution (less than

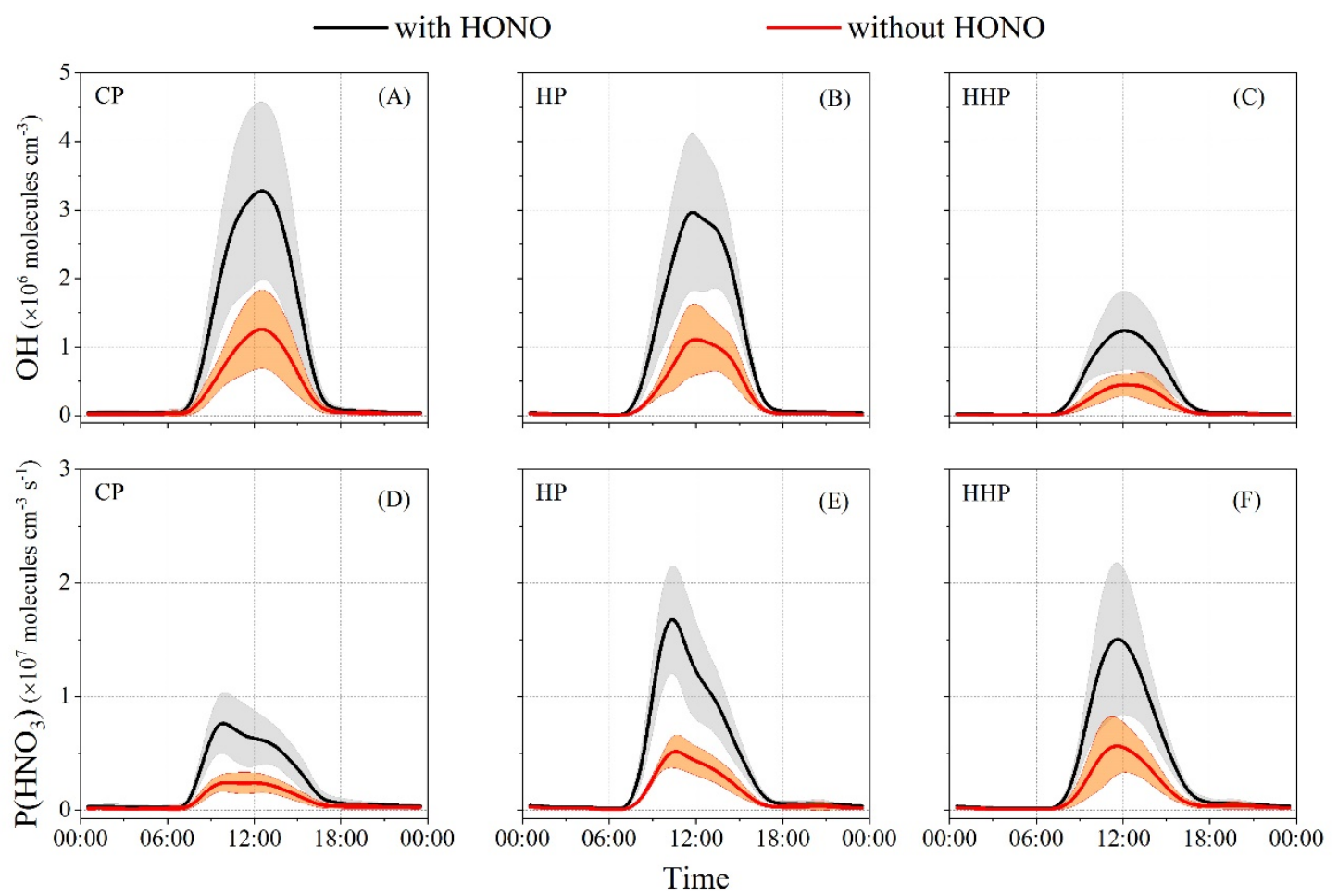

Figure 5. Diurnal profiles of $\mathrm{OH}$ concentrations and potential total nitrate formation rate from gasphase reaction $\mathrm{NO}_{2}+\mathrm{OH}\left(\mathrm{P}\left(\mathrm{HNO}_{3}\right)\right)$ with or without constraint on HONO. The shaded areas represent the standard deviation. 
High $\mathrm{OH}$ production rates due to fast $\mathrm{HONO}$ photolysis lead to high oxidizing capacity with maximum averaged $\mathrm{OH}$ concentrations of $3.3 \times 10^{6}, 3.1 \times 10^{6}$ and $1.3 \times 10^{6}$ molecules $\mathrm{cm}^{-3}$ at noontime during CP, HP, and HHP, respectively. High $\mathrm{OH}$ levels would accelerate the homogeneous formation of nitrate precursor $\mathrm{HNO}_{3}$ through the reaction $\mathrm{NO}_{2}+\mathrm{OH}$, resulting in potential daytime integrated gross nitrate production of $1.7,3.1$ and $2.9 \mu \mathrm{g} \mathrm{m}^{-3} \mathrm{~h}^{-1}$ in the three periods, respectively. Note that the potential daytime gross nitrate production was the upper limit of the particle nitrate production through this path because not all the $\mathrm{HNO}_{3}(\mathrm{~g})$ transformed into particle nitrate. Then we estimated the $\mathrm{HNO}_{3}$ partitioning ratio $\left(\mathrm{HPR}=\mathrm{pNO}_{3} /\left(\mathrm{pNO}_{3}+\mathrm{HNO}_{3}\right)\right)^{59}$ using the measured nitrate and average $\mathrm{HNO}_{3}$ concentration from a winter measurement ${ }^{60}$ (Figure S10). High daytime HPR was found during the campaign, and HPR was higher during HHP $(>0.95)$ than the CP $(>0.8)$, in agreement with the variation of NOR (Figure S11). Meanwhile, one study used the ISORRPIA II model also found a high $\mathrm{HNO}_{3}$ partitioning ratio in the $\mathrm{NCP}$ with an average of $0.8^{59}$. In our study, $\mathrm{NH}_{3}$ concentration was higher and the temperature was much lower than in Wang et al. ${ }^{59}$ (Figure S4), and therefore, the $\mathrm{HNO}_{3}$ partitioning ratio was expected to be higher than $0.8^{30,59}$. Even scaled by $0.8, \mathrm{P}\left(\mathrm{HNO}_{3}\right)$ is still comparable to or even more than that in the summertime at this site (ca. $2.5 \mu \mathrm{g}$ $\left.\mathrm{m}^{-3} \mathrm{~h}^{-1}\right)^{7}$, suggesting the significant nitrate formation from the unexpectedly active photochemistry in winter of this site. Additionally, nitrate production was able to explain the observed particle nitrate concentrations of $2.1,7.3$ and $15.3 \mu \mathrm{g} \mathrm{m}^{-3}$ during the three periods (Table $\mathrm{S} 3$ ), which provides further insight on nitrate pollution in this region. Here we did not consider $\mathrm{N}_{2} \mathrm{O}_{5}$ formed by $\mathrm{NO}_{3}+\mathrm{NO}_{2}$ because the modeled $\mathrm{N}_{2} \mathrm{O}_{5}$ concentrations and production rate were always 1-2 orders of magnitude lower than those by the reaction of $\mathrm{NO}_{2}+\mathrm{OH}$ in the model. The dominant contribution of HONO to the $\mathrm{OH}$ production gave $\mathrm{HONO}$ an indispensable role in the atmospheric oxidizing capacity and hence the secondary pollution such as nitrate (Figure 4 and Figure 5) during wintertime in the NCP. Without constraints by the measured HONO, the $\mathrm{OH}$ and $\mathrm{HO}_{2}$ concentrations will be underestimated by a factor of at least 2, which could further result in a huge underestimation of potential total nitrate formation rates by a factor of more than 2 (Figure 5 and $\mathrm{S} 12$ ) and the formation rates of other secondary pollution, e.g., $\mathrm{O}_{3}$ and $\mathrm{SOA}$, reinforcing the important role of HONO in regional photochemistry and hence the formation of the regional air pollution. Considering the increasing particle nitrate pollution (Figure S13) and the high HONO levels (Figure 1) at this site and other places in the $\mathrm{NCP}^{30}$ during wintertime, our study highlights the critical role of HONO in the radical budget and nitrate formation. It helps to understand the formation of HONO at different pollution levels in the NCP and other similar regions as well.

\section{$410 \quad$ Associated contents}

\section{Supporting Information}

412 The Supporting Information is available free of charge via the Internet at http://pubs.acs.org.

413 Additional details about the campaign and the model, 13 figures (Figure S1-S13), and 3 tables (Table

414 S1-S3) are included.

\section{Author information}

416 Corresponding author

417 *Tel: +86-010-6284-9125. Fax: +86-010-6284-9117. E-mail: yjmu@reccs.ac.cn (Yujing Mu). 
The authors declare no competing financial interest.

\section{Author contributions}

Y.M. designed HONO research. Y.M., J.C., and T.W. organized the field campaign. C.X. performed the HONO measurement, data analysis, and model simulations. C.Z., P.L., and X.Z. performed the measurement of $\mathrm{NO}, \mathrm{NO}_{2}$, and $\mathrm{SO}_{2}$. C.Y. performed the measurement of $\mathrm{H}_{2} \mathrm{O}_{2}$. C.Z. and J.W. performed the OVOCs measurement. H.C. and F.Z. performed the measurement of $\mathrm{NH}_{3}, \mathrm{PAN}$, VOCs, and $\mathrm{PM}_{2.5}$ compositions. J.Z. and J.A. analyzed the $\mathrm{NO}_{\mathrm{x}}$ emission flux and performed the WRF-Chem simulations. J.K., Y.R., and G.K. made helpful comments and suggestions during the model simulations. C.X. and Y.M. wrote this manuscript with all the authors' contributions. J.K., C.V., Y.R., and A.M. revised this manuscript.

\section{Funding sources}

This work was supported by the National Natural Science Foundation of China (No. 41727805, 91544211, 41975164, 41575121, 21707151), the National research program for Key issues in air pollution control (DQGG0103, DQGG0209, DQGG0206), and the National Key Research and Development Program of China (2016YFC0202200, 2017YFC0209703, 2017YFF0108301).

\section{Acknowledgment}

We are grateful to Vanessa Brocchi and François Bernard from Laboratoire de Physique et Chimie de l'Environnement et de l'Espace (LPC2E), Yingnan Zhang and Likun Xue from Shandong University for their helpful discussion about the used box model. We thank all researchers involved in this campaign from Research Centre for Eco-Environmental Sciences-Chinese Academy of Sciences, Fudan University, Hong Kong Polytechnic University, Shandong Jianzhu University, and Shandong University. We thank Liwei Guan and his families for their help throughout all this campaign. C.X. thanks the University of Chinese Academy of Sciences for providing him the UCAS Joint Ph.D. Training Program.

\section{References}

(1) Seinfeld, J. H.; Spyros, N. P. Atmospheric Chemistry and Physics: From Air Pollution to Climate Change; John Wiley \& Sons, 2016.

(2) Lu, K.; Guo, S.; Tan, Z.; Wang, H.; Shang, D.; Liu, Y.; Li, X.; Wu, Z.; Hu, M.; Zhang, Y. Exploring Atmospheric Free-Radical Chemistry in China: The Self-Cleansing Capacity and the Formation of Secondary Air Pollution. Natl. Sci. Rev. 2019, 6 (3), 579-594. https://doi.org/10.1093/nsr/nwy073.

(3) Alicke, B.; Geyer, A.; Hofzumahaus, A.; Holland, F.; Konrad, S.; Pätz, H. W.; Schäfer, J.; Stutz, J.; Volz-Thomas, A.; Platt, U. OH Formation by HONO Photolysis during the BERLIOZ Experiment. J. Geophys. Res. Atmos. 2003, 108 (4), 3-1. https://doi.org/10.1029/2001jd000579.

(4) Kim, S.; Vandenboer, T. C.; Young, C. J.; Riedel, T. P.; Thornton, J. A.; Swarthout, B.; Sive, B.; Lerner, B.; Gilman, J.; Warneke, C.; Roberts, J. M.; Guenther, A.; Wagner, N. L.; Dubé, W. P.; Williams, E.; Brown, S. S. The Primary and Recycling Sources of OH during the NACHTT-2011 Campaign: HONO as an Important $\mathrm{OH}$ Primary Source in the Wintertime. J. Geophys. Res. Atmos. 2014, 119 (11), 6886-6896. https://doi.org/10.1002/2013JD019784.

(5) Elshorbany, Y. F.; Kleffmann, J.; Kurtenbach, R.; Lissi, E.; Rubio, M.; Villena, G.; Gramsch, E.; Rickard, A. R.; Pilling, M. J.; Wiesen, P. Seasonal Dependence of the Oxidation Capacity of the 
https://doi.org/10.1016/j.atmosenv.2009.08.036.

(6) Tan, Z.; Rohrer, F.; Lu, K.; Ma, X.; Bohn, B.; Broch, S.; Dong, H.; Fuchs, H.; Gkatzelis, G. I.; Hofzumahaus, A.; Holland, F.; Li, X.; Liu, Y.; Liu, Y.; Novelli, A.; Shao, M.; Wang, H.; Wu, Y.; Zeng, L.; Hu, M.; Kiendler-Scharr, A.; Wahner, A.; Zhang, Y. Wintertime Photochemistry in Beijing: Observations of $\mathrm{RO}_{\mathrm{x}}$ Radical Concentrations in the North China Plain during the BESTONE Campaign. Atmos. Chem. Phys. 2018, 18 (16), 12391-12411. https://doi.org/10.5194/acp18-12391-2018.

(7) Tan, Z.; Fuchs, H.; Lu, K.; Hofzumahaus, A.; Bohn, B.; Broch, S.; Dong, H.; Gomm, S.; Häseler, R.; He, L.; Holland, F.; Li, X.; Liu, Y.; Lu, S.; Rohrer, F.; Shao, M.; Wang, B.; Wang, M.; Wu, Y.; Zeng, L.; Zhang, Y.; Wahner, A.; Zhang, Y. Radical Chemistry at a Rural Site (Wangdu) in the North China Plain: Observation and Model Calculations of $\mathrm{OH}, \mathrm{HO}_{2}$ and $\mathrm{RO}_{2}$ Radicals. Atmos. Chem. Phys. 2017, 17 (1), 663-690. https://doi.org/10.5194/acp-17-663-2017.

(8) Slater, E. J.; Whalley, L. K.; Woodward-massey, R.; Ye, C.; Lee, J. D.; Squires, F.; Hopkins, J. R.; Dunmore, R. E.; Shaw, M.; Hamilton, J. F.; Lewis, A. C.; Crilley, L. R.; Kramer, L.; Bloss, W.; Vu, T.; Sun, Y.; Xu, W.; Yue, S.; Ren, L.; Acton, W. J. F.; Hewitt, C. N.; Wang, X.; Fu, P.; Heard, D. E. Elevated Levels of OH Observed in Haze Events during Wintertime in Central Beijing. Atmos. Chem. Phys. Discuss. 2020. https://doi.org/10.5194/acp-2020-362.

(9) Kurtenbach, R.; Becker, K. H.; Gomes, J. A. G.; Kleffmann, J.; Lörzer, J. C.; Spittler, M.; Wiesen, P.; Ackermann, R.; Geyer, A.; Platt, U. Investigations of Emissions and Heterogeneous Formation of HONO in a Road Traffic Tunnel. Atmos. Environ. 2001, 35 (20), 3385-3394. https://doi.org/10.1016/S1352-2310(01)00138-8.

(10) Nakashima, Y.; Sadanaga, Y.; Saito, S.; Hoshi, J.; Ueno, H. Contributions of Vehicular Emissions and Secondary Formation to Nitrous Acid Concentrations in Ambient Urban Air in Tokyo in the Winter. Sci. Total Environ. 2017, 592, 178-186. https://doi.org/10.1016/j.scitotenv.2017.03.122.

(11) Trinh, H. T.; Imanishi, K.; Morikawa, T.; Hagino, H.; Takenaka, N. Gaseous Nitrous Acid (HONO) and Nitrogen Oxides $\left(\mathrm{NO}_{\mathrm{x}}\right)$ Emission from Gasoline and Diesel Vehicles under RealWorld Driving Test Cycles. J. Air Waste Manag. Assoc. 2017, 67 (4), 412-420. https://doi.org/10.1080/10962247.2016.1240726.

(12) Liu, Y.; Lu, K.; Ma, Y.; Yang, X.; Zhang, W.; Wu, Y.; Peng, J.; Shuai, S.; Hu, M.; Zhang, Y. Direct Emission of Nitrous Acid (HONO) from Gasoline Cars in China Determined by Vehicle Chassis Dynamometer Experiments. Atmos. Environ. 2017, 169, 89-96. https://doi.org/10.1016/j.atmosenv.2017.07.019.

(13) Kirchstetter, T. W.; Harley, R. A.; Littlejohn, D. Measurement of Nitrous Acid in Motor Vehicle Exhaust. Environ. Sci. Technol. 1996, 30 (9), 2843-2849. https://doi.org/10.1021/es960135y.

(14) Kleffmann, J.; Kurtenbach, R.; Lörzer, J.; Wiesen, P.; Kalthoff, N.; Vogel, B.; Vogel, H. Measured and Simulated Vertical Profiles of Nitrous Acid - Part I: Field Measurements. Atmos. Environ. 2003, 37 (21), 2949-2955. https://doi.org/10.1016/S1352-2310(03)00242-5.

(15) Laufs, S.; Cazaunau, M.; Stella, P.; Kurtenbach, R.; Cellier, P.; Mellouki, A.; Loubet, B.; Kleffmann, J. Diurnal Fluxes of HONO above a Crop Rotation. Atmos. Chem. Phys. 2017, 17 (11), 6907-6923. https://doi.org/10.5194/acp-17-6907-2017.

(16) Stemmler, K.; Ammann, M.; Donders, C.; Kleffmann, J.; George, C. Photosensitized Reduction of Nitrogen Dioxide on Humic Acid as a Source of Nitrous Acid. Nature 2006, 440 (7081), 195198. https://doi.org/10.1038/nature04603.

(17) Han, C.; Yang, W.; Wu, Q.; Yang, H.; Xue, X. Heterogeneous Photochemical Conversion of $\mathrm{NO}_{2}$ 
to HONO on the Humic Acid Surface under Simulated Sunlight. Environ. Sci. Technol. 2016, 50 (10), 5017-5023. https://doi.org/10.1021/acs.est.5b05101.

(18) Zhou, X.; Zhang, N.; Teravest, M.; Tang, D.; Hou, J.; Bertman, S.; Alaghmand, M.; Shepson, P. B.; Carroll, M. A.; Griffith, S.; Dusanter, S.; Stevens, P. S. Nitric Acid Photolysis on Forest Canopy Surface as a Source for Tropospheric Nitrous Acid. Nat. Geosci. 2011, 4 (7), 440-443. https://doi.org/10.1038/ngeo1164.

(19) Ye, C.; Zhou, X.; Pu, D.; Stutz, J.; Festa, J.; Spolaor, M.; Tsai, C.; Cantrell, C.; Mauldin, R. L.; Campos, T.; Weinheimer, A.; Hornbrook, R. S.; Apel, E. C.; Guenther, A.; Kaser, L.; Yuan, B.; Karl, T.; Haggerty, J.; Hall, S.; Ullmann, K.; Smith, J. N.; Ortega, J.; Knote, C. Rapid Cycling of Reactive Nitrogen in the Marine Boundary Layer. Nature 2016, 532 (7600), 489-491. https://doi.org/10.1038/nature17195.

(20) Bao, F.; Li, M.; Zhang, Y.; Chen, C.; Zhao, J. Photochemical Aging of Beijing Urban $\mathrm{PM}_{2.5}$ : HONO Production. Environ. Sci. Technol. 2018, 52 (11), 6309-6316. https://doi.org/10.1021/acs.est.8b00538.

(21) Oswald, R.; Behrendt, T.; Ermel, M.; Wu, D.; Su, H.; Cheng, Y.; Breuninger, C.; Moravek, A.; Mougin, E.; Delon, C.; Loubet, B.; Pommerening-Röser, A.; Sörgel, M.; Pöschl, U.; Hoffmann, T.; Andreae, M. O.; Meixner, F. X.; Trebs, I. HONO Emissions from Soil Bacteria as a Major Source of Atmospheric Reactive Nitrogen. Science 2013, 341 (6151), 1233-1235. https://doi.org/10.1126/science.1242266.

(22) Su, H.; Cheng, Y.; Oswald, R.; Behrendt, T.; Trebs, I.; Meixner, F. X.; Andreae, M. O.; Cheng, P.; Zhang, Y.; Poschl, U. Soil Nitrite as a Source of Atmospheric HONO and OH Radicals. Science 2011, 333 (6049), 1616-1618. https://doi.org/10.1126/science.1207687.

(23) Bejan, I.; Abd El Aal, Y.; Barnes, I.; Benter, T.; Bohn, B.; Wiesen, P.; Kleffmann, J. The Photolysis of Ortho-Nitrophenols: A New Gas Phase Source of HONO. Phys. Chem. Chem. Phys. 2006, 8 (17), 2028-2035. https://doi.org/10.1039/b516590c.

(24) Aumont, B.; Chervier, F.; Laval, S. Contribution of HONO Sources to the $\mathrm{NO}_{\mathrm{x}} / \mathrm{HO}_{\mathrm{x}} / \mathrm{O}_{3}$ Chemistry in the Polluted Boundary Layer. Atmos. Environ. 2003, 37 (4), 487-498. https://doi.org/10.1016/S1352-2310(02)00920-2.

(25) Vogel, B.; Vogel, H.; Kleffmann, J.; Kurtenbach, R. Measured and Simulated Vertical Profiles of Nitrous Acid - Part II. Model Simulations and Indications for a Photolytic Source. Atmos. Environ. 2003, 37 (21), 2957-2966. https://doi.org/10.1016/S1352-2310(03)00243-7.

(26) Xing, L.; Wu, J.; Elser, M.; Tong, S.; Liu, S.; Li, X.; Liu, L.; Cao, J.; Zhou, J.; El-Haddad, I.; Huang, R.; Ge, M.; Tie, X.; Prévôt, A. S. H.; Li, G. Wintertime Secondary Organic Aerosol Formation in Beijing-Tianjin-Hebei (BTH): Contributions of HONO Sources and Heterogeneous Reactions. Atmos. Chem. Phys. 2019, 19 (4), 2343-2359. https://doi.org/10.5194/acp-19-23432019.

(27) Qu, Y.; Chen, Y.; Liu, X.; Zhang, J.; Guo, Y.; An, J. Seasonal Effects of Additional HONO Sources and the Heterogeneous Reactions of $\mathrm{N}_{2} \mathrm{O}_{5}$ on Nitrate in the North China Plain. Sci. Total Environ. 2019, 690, 97-107. https://doi.org/10.1016/j.scitotenv.2019.06.436.

(28) Li, D.; Xue, L.; Wen, L.; Wang, X.; Chen, T.; Mellouki, A.; Chen, J.; Wang, W. Characteristics and Sources of Nitrous Acid in an Urban Atmosphere of Northern China: Results from 1-yr Continuous Observations. Atmos. Environ. 2018, 182, 296-306. https://doi.org/10.1016/j.atmosenv.2018.03.033.

(29) Zhang, W.; Tong, S.; Ge, M.; An, J.; Shi, Z.; Hou, S.; Xia, K.; Qu, Y.; Zhang, H.; Chu, B.; Sun, 
Y.; He, H. Variations and Sources of Nitrous Acid (HONO) during a Severe Pollution Episode in Beijing in Winter 2016. Sci. Total Environ. 2019, 648, 253-262. https://doi.org/10.1016/j.scitotenv.2018.08.133.

(30) Wen, L.; Xue, L.; Wang, X.; Xu, C.; Chen, T.; Yang, L.; Wang, T.; Zhang, Q.; Wang, W. Summertime Fine Particulate Nitrate Pollution in the North China Plain: Increasing Trends, Formation Mechanisms and Implications for Control Policy. Atmos. Chem. Phys. 2018, 18 (15), 11261-11275. https://doi.org/10.5194/acp-18-11261-2018.

(31) Laufs, S.; Kleffmann, J. Investigations on HONO Formation from Photolysis of Adsorbed $\mathrm{HNO}_{3}$ on Quartz Glass Surfaces. Phys. Chem. Chem. Phys. 2016, 18 (14), 9616-9625. https://doi.org/10.1039/c6cp00436a.

(32) Romer, P. S.; Wooldridge, P. J.; Crounse, J. D.; Kim, M. J.; Wennberg, P. O.; Dibb, J. E.; Scheuer, E.; Blake, D. R.; Meinardi, S.; Brosius, A. L.; Thames, A. B.; Miller, D. O.; Brune, W. H.; Hall, S. R.; Ryerson, T. B.; Cohen, R. C. Constraints on Aerosol Nitrate Photolysis as a Potential Source of HONO and $\mathrm{NO}_{\mathrm{x}}$. Environ. Sci. Technol. 2018, 52 (23), 13738-13746. https://doi.org/10.1021/acs.est.8b03861.

(33) Fu, X.; Wang, T.; Zhang, L.; Li, Q.; Wang, Z.; Xia, M.; Yun, H.; Wang, W.; Yu, C.; Yue, D.; Zhou, Y.; Zheng, J.; Han, R. The Significant Contribution of HONO to Secondary Pollutants during a Severe Winter Pollution Event in Southern China. Atmos. Chem. Phys. 2019, 19 (1), 1-14. https://doi.org/10.5194/acp-19-1-2019.

(34) Xue, C.; Ye, C.; Ma, Z.; Liu, P.; Zhang, Y.; Zhang, C.; Tang, K.; Zhang, W.; Zhao, X.; Wang, Y.; Song, M.; Liu, J.; Duan, J.; Qin, M.; Tong, S.; Ge, M.; Mu, Y. Development of Stripping CoilIon Chromatograph Method and Intercomparison with CEAS and LOPAP to Measure Atmospheric HONO. Sci. Total Environ. 2019, 646, 187-195. https://doi.org/10.1016/j.scitotenv.2018.07.244.

(35) Heland, J.; Kleffmann, J.; Kurtenbach, R.; Wiesen, P. A New Instrument to Measure Gaseous Nitrous Acid (HONO) in the Atmosphere. Environ. Sci. Technol. 2001, 35 (15), 3207-3212. https://doi.org/10.1021/es000303t.

(36) Kleffmann, J.; Lörzer, J. C.; Wiesen, P.; Kern, C.; Trick, S.; Volkamer, R.; Rodenas, M.; Wirtz, $\mathrm{K}$. Intercomparison of the DOAS and LOPAP Techniques for the Detection of Nitrous Acid (HONO). Atmos. Environ. 2006, 40 (20), 3640-3652. https://doi.org/10.1016/j.atmosenv.2006.03.027.

(37) Crilley, L. R.; Kramer, L. J.; Ouyang, B.; Duan, J.; Zhang, W.; Tong, S.; Ge, M.; Tang, K.; Qin, M.; Xie, P.; Shaw, M. D.; Lewis, A. C.; Mehra, A.; Bannan, T. J.; Worrall, S. D.; Priestley, M.; Bacak, A.; Coe, H.; Allan, J.; Percival, C. J.; Popoola, O. A. M.; Jones, R. L.; Bloss, W. J. Intercomparison of Nitrous Acid (HONO) Measurement Techniques in a Megacity (Beijing). Atmos. Meas. Tech. 2019, 12 (12), 6449-6463. https://doi.org/10.5194/amt-12-6449-2019.

(38) Sommariva, R.; Cox, S.; Martin, C.; Borońska, K.; Young, J.; Jimack, P. K.; Pilling, M. J.; Matthaios, V. N.; Nelson, B. S.; Newland, M. J.; Panagi, M.; Bloss, W. J.; Monks, P. S.; Rickard, A. R. AtChem (Version 1), an Open-Source Box Model for the Master Chemical Mechanism. Geosci. Model Dev. 2020, 13 (1), 169-183. https://doi.org/10.5194/gmd-13-169-2020.

(39) Svoboda, O.; Kubelová, L.; Slavíček, P. Enabling Forbidden Processes: Quantum and Solvation Enhancement of Nitrate Anion UV Absorption. J. Phys. Chem. A 2013, 117 (48), 12868-12877. https://doi.org/10.1021/jp4098777.

(40) Li, G.; Lei, W.; Zavala, M.; Volkamer, R.; Dusanter, S.; Stevens, P.; Molina, L. T. Impacts of 
HONO Sources on the Photochemistry in Mexico City during the MCMA-2006/MILAGO Campaign. Atmos. Chem. Phys. 2010, 10 (14), 6551-6567. https://doi.org/10.5194/acp-10-65512010.

(41) Villena, G.; Kleffmann, J.; Kurtenbach, R.; Wiesen, P.; Lissi, E.; Rubio, M. A.; Croxatto, G.; Rappenglück, B. Vertical Gradients of $\mathrm{HONO}, \mathrm{NO}_{x}$ and $\mathrm{O}_{3}$ in Santiago de Chile. Atmos. Environ. 2011, 45 (23), 3867-3873. https://doi.org/10.1016/j.atmosenv.2011.01.073.

(42) Wong, K. W.; Tsai, C.; Lefer, B.; Haman, C.; Grossberg, N.; Brune, W. H.; Ren, X.; Luke, W.; Stutz, J. Daytime HONO Vertical Gradients during SHARP 2009 in Houston, TX. Atmos. Chem. Phys. 2012, 12 (2), 635-652. https://doi.org/10.5194/acp-12-635-2012.

(43) Xu, Z.; Wang, T.; Wu, J.; Xue, L.; Chan, J.; Zha, Q.; Zhou, S.; Louie, P. K. K.; Luk, C. W. Y. Nitrous Acid (HONO) in a Polluted Subtropical Atmosphere: Seasonal Variability, Direct Vehicle Emissions and Heterogeneous Production at Ground Surface. Atmos. Environ. 2015, 106, 100109. https://doi.org/10.1016/j.atmosenv.2015.01.061.

(44) Lee, J. D.; Whalley, L. K.; Heard, D. E.; Stone, D.; Dunmore, R. E.; Hamilton, J. F.; Young, D. E.; Allan, J. D.; Laufs, S.; Kleffmann, J. Detailed Budget Analysis of HONO in Central London Reveals a Missing Daytime Source. Atmos. Chem. Phys. 2016, 16 (5), 2747-2764. https://doi.org/10.5194/acp-16-2747-2016.

(45) Zhang, J.; Chen, J.; Xue, C.; Chen, H.; Zhang, Q.; Liu, X.; Mu, Y.; Guo, Y.; Wang, D.; Chen, Y.; Li, J.; Qu, Y.; An, J. Impacts of Six Potential HONO Sources on $\mathrm{HO}_{\mathrm{x}}$ Budgets and SOA Formation during a Wintertime Heavy Haze Period in the North China Plain. Sci. Total Environ. 2019, 681, 110-123. https://doi.org/10.1016/j.scitotenv.2019.05.100.

(46) Ji, Y.; Qin, X.; Wang, B.; Xu, J.; Shen, J.; Chen, J.; Huang, K.; Deng, C.; Yan, R.; Xu, K.; Zhang, T. Counteractive Effects of Regional Transport and Emission Control on the Formation of Fine Particles: A Case Study during the Hangzhou G20 Summit. Atmos. Chem. Phys. 2018, 18 (18), 13581-13600. https://doi.org/10.5194/acp-18-13581-2018.

(47) Heard, D. E.; Carpenter, L. J.; Creasey, D. J.; Hopkins, J. R.; Lee, J. D.; Lewis, A. C.; Pilling, M. J.; Seakins, P. W.; Carslaw, N.; Emmerson, K. M. High Levels of the Hydroxyl Radical in the Winter Urban Troposphere. Geophys. Res. Lett. 2004, 31 (18). https://doi.org/10.1029/2004GL020544.

(48) Michoud, V.; Colomb, A.; Borbon, A.; Miet, K.; Beekmann, M.; Camredon, M.; Aumont, B.; Perrier, S.; Zapf, P.; Siour, G.; Ait-Helal, W.; Afif, C.; Kukui, A.; Furger, M.; Dupont, J. C.; Haeffelin, M.; Doussin, J. F. Study of the Unknown HONO Daytime Source at a European Suburban Site during the MEGAPOLI Summer and Winter Field Campaigns. Atmos. Chem. Phys. 2014, 14 (6), 2805-2822. https://doi.org/10.5194/acp-14-2805-2014.

(49) Edwards, P. M.; Brown, S. S.; Roberts, J. M.; Ahmadov, R.; Banta, R. M.; DeGouw, J. A.; Dubé, W. P.; Field, R. A.; Flynn, J. H.; Gilman, J. B.; Graus, M.; Helmig, D.; Koss, A.; Langford, A. O.; Lefer, B. L.; Lerner, B. M.; Li, R.; Li, S. M.; McKeen, S. A.; Murphy, S. M.; Parrish, D. D.; Senff, C. J.; Soltis, J.; Stutz, J.; Sweeney, C.; Thompson, C. R.; Trainer, M. K.; Tsai, C.; Veres, P. R.; Washenfelder, R. A.; Warneke, C.; Wild, R. J.; Young, C. J.; Yuan, B.; Zamora, R. High Winter Ozone Pollution from Carbonyl Photolysis in an Oil and Gas Basin. Nature 2014, 514 (7522), 351-354. https://doi.org/10.1038/nature13767.

(50) Zhang, L.; Wang, T.; Zhang, Q.; Zheng, J.; Xu, Z.; Lv, M. Potential Sources of Nitrous Acid (HONO) and Their Impacts on Ozone: A WRF-Chem Study in a Polluted Subtropical Region. $J$. Geophys. Res. Atmos. 2016, 121 (7), 3645-3662. https://doi.org/10.1002/2015JD024468. 
(51) Wong, K. W.; Tsai, C.; Lefer, B.; Grossberg, N.; Stutz, J. Modeling of Daytime HONO Vertical Gradients during SHARP 2009. Atmos. Chem. Phys. 2013, 13 (7), 3587-3601. https://doi.org/10.5194/acp-13-3587-2013.

(52) Zhang, J.; An, J.; Qu, Y.; Liu, X.; Chen, Y. Impacts of Potential HONO Sources on the Concentrations of Oxidants and Secondary Organic Aerosols in the Beijing-Tianjin-Hebei Region of China. Sci. Total Environ. 2019, 647, 836-852. https://doi.org/10.1016/j.scitotenv.2018.08.030.

(53) Zhang, W.; Tong, S.; Ge, M.; An, J.; Shi, Z.; Hou, S.; Xia, K.; Qu, Y.; Zhang, H.; Chu, B.; Sun, Y.; He, H. Variations and Sources of Nitrous Acid (HONO) during a Severe Pollution Episode in Beijing in Winter 2016. Sci. Total Environ. 2019, 648, 253-262. https://doi.org/10.1016/j.scitotenv.2018.08.133.

(54) Lin, Y. C.; Cheng, M. T.; Ting, W. Y.; Yeh, C. R. Characteristics of Gaseous $\mathrm{HNO}_{2}, \mathrm{HNO}_{3}, \mathrm{NH}_{3}$ and Particulate Ammonium Nitrate in an Urban City of Central Taiwan. Atmos. Environ. 2006, 40 (25), 4725-4733. https://doi.org/10.1016/j.atmosenv.2006.04.037.

(55) Elshorbany, Y. F.; Kurtenbach, R.; Wiesen, P.; Lissi, E.; Rubio, M.; Villena, G.; Gramsch, E.; Rickard, A. R.; Pilling, M. J.; Kleffmann, J. Oxidation Capacity of the City Air of Santiago, Chile. Atmos. Chem. Phys. 2009, 9 (6), 2257-2273. https://doi.org/10.5194/acp-9-2257-2009.

(56) Liu, Y.; Lu, K.; Li, X.; Dong, H.; Tan, Z.; Wang, H.; Zou, Q.; Wu, Y.; Zeng, L.; Hu, M.; Min, K. E.; Kecorius, S.; Wiedensohler, A.; Zhang, Y. A Comprehensive Model Test of the HONO Sources Constrained to Field Measurements at Rural North China Plain. Environ. Sci. Technol. 2019, 53 (7), 3517-3525. https://doi.org/10.1021/acs.est.8b06367.

(57) Kleffmann, J. Daytime Sources of Nitrous Acid (HONO) in the Atmospheric Boundary Layer. ChemPhysChem. 2007, 8(8), 1137-1144. https://doi.org/10.1002/cphc.200700016.

(58) Villena, G.; Wiesen, P.; Cantrell, C. A.; Flocke, F.; Fried, A.; Hall, S. R.; Hornbrook, R. S.; Knapp, D.; Kosciuch, E.; Mauldin, R. L.; McGrath, J. A.; Montzka, D.; Richter, D.; Ullmann, K.; Walega, J.; Weibring, P.; Weinheimer, A.; Staebler, R. M.; Liao, J.; Huey, L. G.; Kleffmann, J. Nitrous Acid (HONO) during Polar Spring in Barrow, Alaska: A Net Source of OH Radicals? J. Geophys. Res. Atmos. 2011, 116 (24), 1-12. https://doi.org/10.1029/2011JD016643.

(59) Wang, H.; Lu, K.; Chen, X.; Zhu, Q.; Chen, Q.; Guo, S.; Jiang, M.; Li, X.; Shang, D.; Tan, Z.; Wu, Y.; Wu, Z.; Zou, Q.; Zheng, Y.; Zeng, L.; Zhu, T.; Hu, M.; Zhang, Y. High $\mathrm{N}_{2} \mathrm{O}_{5}$ Concentrations Observed in Urban Beijing: Implications of a Large Nitrate Formation Pathway. Environ. Sci. Technol. Lett. 2017, 4 (10), 416-420. https://doi.org/10.1021/acs.estlett.7b00341.

(60) Song, S.; Gao, M.; Xu, W.; Shao, J.; Shi, G.; Wang, S.; Wang, Y.; Sun, Y.; McElroy, M. B. FineParticle $\mathrm{pH}$ for Beijing Winter Haze as Inferred from Different Thermodynamic Equilibrium Models. Atmos. Chem. Phys. 2018, 18 (10), 7423-7438. https://doi.org/10.5194/acp-18-74232018. 